\title{
Using object-based geomorphometry for hydro-geomorphological analysis in a Mediterranean research catchment
}

\author{
Domenico Guida $^{1}$, Albina Cuomo ${ }^{1}$, and Vincenzo Palmieri ${ }^{2}$ \\ ${ }^{1}$ Department of Civil Engineering, University of Salerno, Fisciano, 84084, Italy \\ ${ }^{2}$ ARCADIS, Agency for Soil Defense of the Campania Region, Naples, Italy \\ Correspondence to: Albina Cuomo (acuomo@unisa.it) \\ Received: 11 February 2016 - Published in Hydrol. Earth Syst. Sci. Discuss.: 9 March 2016 \\ Revised: 28 July 2016 - Accepted: 1 August 2016 - Published: 31 August 2016
}

\begin{abstract}
The aim of the paper is to apply an object-based geomorphometric procedure to define the runoff contribution areas and support a hydro-geomorphological analysis of a $3 \mathrm{~km}^{2}$ Mediterranean research catchment (southern Italy). Daily and sub-hourly discharge and electrical conductivity data were collected and recorded during a 3-year monitoring activity. Hydro-chemograph analyses carried out on these data revealed a strong seasonal hydrological response in the catchment that differed from the stormflow events that occur in the wet periods and in dry periods. This analysis enabled us to define the hydro-chemograph signatures related to increasing flood magnitude, which progressively involves various runoff components (baseflow, subsurface flow and surficial flow) and an increasing contributing area to discharge. Field surveys and water table/discharge measurements carried out during a selected storm event enabled us to identify and map specific runoff source areas with homogeneous geomorphological units previously defined as hydrogeomorphotypes (spring points, diffuse seepage along the main channel, seepage along the riparian corridors, diffuse outflow from hillslope taluses and concentrate sapping from colluvial hollows). Following the procedures previously proposed and used by authors for object-based geomorphological mapping, a hydro-geomorphologically oriented segmentation and classification was performed with the eCognition (Trimble, Inc.) package. The best agreement with the expert-based geomorphological mapping was obtained with weighted plan curvature at different-sized windows. By combining the hydro-chemical analysis and object-based hydrogeomorphotype map, the variability of the contribution areas was graphically modeled for the selected event, which occurred during the wet season, by using the log values of
\end{abstract}

flow accumulation that better fit the contribution areas. The results allow us to identify the runoff component on hydrochemographs for each time step and calculate a specific discharge contribution from each hydro-geomorphotype. This kind of approach could be useful when applied to similar, rainfall-dominated, forested and no-karst catchments in the Mediterranean eco-region.

\section{Introduction}

In order to gain a better understanding of hydrology, it is essential to study the complex interactions and linkages between watershed components, such as drainage network, riparian corridors, headwaters, hillslopes and aquifers and related processes operating at multiple scales (National Research Council, 1999). Hydrological science plays an important and fundamental role only when it provides an integrated knowledge and understanding of the forms and processes that operate in watersheds at multiple space-time scales in the landscape (Marcus et al., 2004). A useful way of understanding the response of catchments to rainfall events is to analyze stream discharge vs. rainfall per unit of time, plotted as a storm flow hydrograph and hyetograph, respectively. In recent decades, hydrologists have carried out numerous studies on catchment and hillslope hydrology in order to define when, how and where runoff is produced and how it progressively increases along the drainage network. Hydrologists generally agree that following rainfall, new-event water components are added to the old, pre-event water components through various hydrological mechanisms that are generally referred to as baseflow components that are derived 
from deep and shallow aquifers, thus expanding and reducing the runoff-contributing areas (Betson, 1964). The most common general concept that explains the above-mentioned hysteretic behavior is the variable source area (VSA) concept. This concept was originally proposed by Hewlett (1961) and later adopted by other authors (Dunne and Black, 1970; Dunne and Leopold, 1978; Huang and Laften, 1996; Vander Kwaak and Loague, 2001; Zollweg et al., 1995, Pionke et al., 1996). Despite its early formulation, it has provided the hydrological background for more recent research studies (Lyon et al., 2004, Easton et al., 2007, 2008; Buchanan et al., 2012; Moore et al., 1988; Barling et al., 1994; Kwaad, 1991; Easton et al., 2010; White et al., 2011). Contemporarily, the "hydro-geomorphic paradigm" was proposed by Sidle et al. (2000) in order to discriminate the VSA hydrologic sources and pathways, which refers to the connected hydrogeomorphic components of the catchments (hollow, hillslope and riparian corridor). Within a more general program for flood hazard assessment procedures, the hydro-geomorphic paradigm was used to generalize at basin and regional scale in southern Italy by Cuomo (2012), by means of hydrogeomorphology (Okunishi, 1991, 1994; Babar, 2005; Sidle and Onda, 2004; Goerl et al., 2012). Cuomo (2012) introduced and applied a new hydro-geomorphological basic unit, the hydro-geomorphotype, by using the Salerno Geomorphological Mapping System (Dramis et al., 2011; Guida et al., $2012,2015)$ as a framework for object-based geomorphological mapping. Based on the up-to-date and shared theoretical geomorphometric background (Baatz and Schäpe, 2000; Dragut and Blaschke, 2006; van Asselen and Seijmonsbergen, 2006; Anders et al., 2011; Dragut et al., 2013, 2014; Eisank et al., 2014), this proposal is currently under experimental calibration as an effective, object-based geomorphometric procedure for spatial individuation, objective delimitation and automatic recognition of the hydrogeomorphotypes from the perspective of an object-based distributed hydrological modeling (Cuomo et al., 2012).

Linking geomorphometry with hydrology towards hydrogeomorphology gives consistency to the suggestion made by Peckham (2009) with the aim of simplifying the issue of the computational cost and time of a fully distributed model.

In the past, many authors made extensive use of chemical and isotopic tracers in order to separate the runoff components recorded in the hydrographs and pinpoint distinctive sources and pathways by using the geochemical and isotopic signature of water at parcel scale or for small catchments (Klaus and McDonnell, 2013). However, applying only the hydro-chemograph and isotopic separation methods to an experimental parcel cannot provide sufficient information on the spatial distribution of runoff sources and paths for basins as a whole, due to their spatial heterogeneity structure and time process variability.

Moreover, extensive use of the above-mentioned methods is more expensive and time-consuming than the quantity and quality of the data collected and the knowledge gained. As stated by Ladouche et al. (2001), with these methods alone it is possible to identify the type, timing and volume of the runoff components, but it is impossible to define the spatial origin and related pathways during storm events accurately. In order to overcome these difficulties and by following the general approach used by Latron and Gallart (2007), we used an integrated, hydro-geomorphological approach for studying a Mediterranean research catchment in southern Italy. This approach is based on detailed geomorphological surveys, mapping and 3-year hydro-chemical monitoring. It integrates a new procedure for identifying and separating hydro-chemical runoff components and a geomorphometric application for the objective delimitation of the source areas, where each runoff component is generated (Cuomo and Guida, 2013; Guida and Cuomo, 2014). Starting from these premises, the paper describes the study area as a Mediterranean research catchment and presents the hydro-chemical data set recorded during the monitoring activity carried out in the 2013-2014 calibration period. In the next section an original procedure is described for determining the timing, type and hydro-chemical signature of the runoff components involved during storm events. With the aim of spatially defining these runoff sources, an objectbased hydro-geomorphological map was then set by hydrologically oriented segmentation and classification. Finally, the results of combined hydro-chemical and object-based hydro-geomorphometric analysis are discussed in order to determine the variability of the contributing area during a significant storm event (see the storm event hydro-chemical data set in the Supplement data).

\section{Hydro-geomorphology and monitoring activity of the study area}

The study area is a forested and hilly catchment located in the Bussento River drainage basin, the $3 \mathrm{~km}^{2}$ Ciciriello catchment in the Cilento and Vallo di Diano National ParkUNESCO Global Geopark, southern Italy (Fig. 1).

At the base the terrigenous bedrock is composed of a lower Tertiary, marly-clayey formation passing in unconformity upward to middle Miocene, westward-dipping sandstone strata and pelitic intervals. A lenticular $10 \mathrm{~m}$ thick marly layer ("Fogliarina Marl", as a geosite in the Geopark) outcrops along the right-hand side of the valley. Regosols, regolite and gravelly slope deposits up to $5 \mathrm{~m}$ thick cover the above-mentioned bedrock. The mainstream bed, rectilinear and dipping strata subsequent to main faults is incised in alluvial gravelly and smooth deposits and partly in bedrock; the secondary streambed is exclusively in bedrock, subsequent to minor fault systems. From a hydro-geomorphological perspective, the groundwater circulation is controlled by the litho-structural arrangement of the above-mentioned bedrock formations, where the marly-clayey formation constitutes the local aquitard below the sandstone aquifer. The westward dipping of the permeability boundary causes a general 


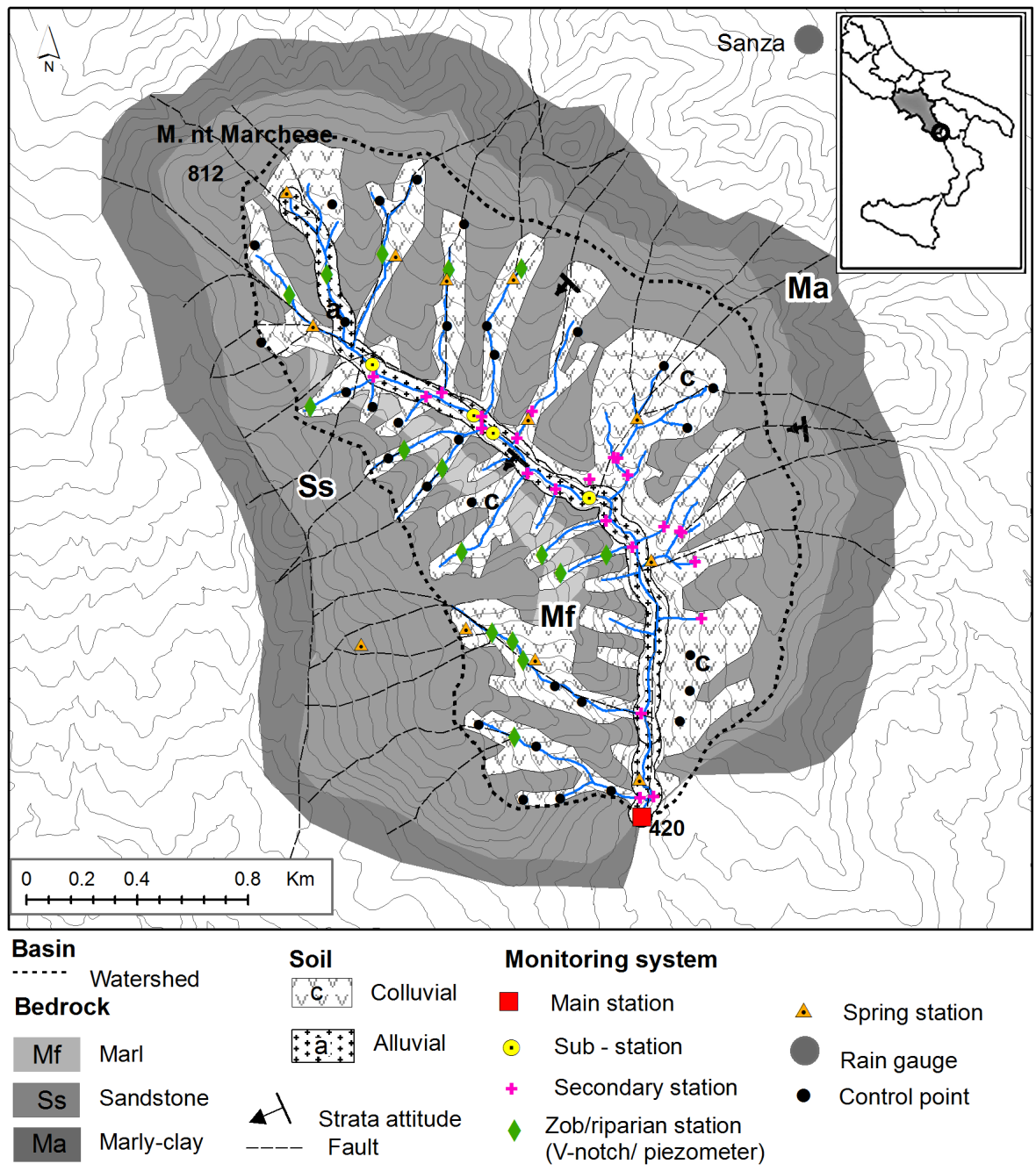

Figure 1. Hydrogeological map of the Ciciriello Experimental Catchment and location of the monitoring stations (modified from Cuomo and Guida, 2016). Legend: bedrock lithology: Ma, marly clay and argillite Tertiary formation, and base aquiclude; Ss, sandstone Miocene formation, and fractured general aquifer; Mf, marl, interlayered and perched aquifer.

westward groundwater flow, convergent toward the lower apex of the wedge-like hydro-structures ("hydro-wedge" in Cascini at al., 2008 and Cuomo and Guida, 2016), where the main permanent springs are located. In the headwaters, colluvial hollows are situated at the bottom of the zero-order basins, and are considered to be the main headwater hydrogeomorphotypes by Cuomo (2012), where dominant saturation excess runoff occurs mainly during the wet season. The streamflow of both permanent springs from the bedrock aquifers and seasonal springs from colluvial headwater increase down valley.

From December 2012, water depth $(D)$, discharge $(Q)$ and specific electrical conductivity (we used either SEC or EC in the following) were measured daily at the main station, hourly during the floods and weekly at the sub-stations during the inter-storm periods (Fig. 1). The $Q$ measurements were obtained with the Swoffer 3000 current meter (Swof- fer Inc., USA), and the EC parameter was measured with multi-parametric probe HI9828 (Hanna Instruments Inc., Romania). The monitoring year 2013-2014 (Fig. 2) provided a complete hydro-chemical data set, which enabled us to carry out the analysis at seasonal and event timescales (Cuomo and Guida, 2014).

\section{Hydro-geomorphological procedure for the contributing areas' individuation}

The contributing area is a dynamic hydrological concept because it may vary seasonally. The extension of the contributing area is strongly influenced by various static factors such as topography and soils, and dynamic factors such as antecedent moisture conditions, rainfall characteristics (Dunne and Black, 1970) and vegetation cover. 


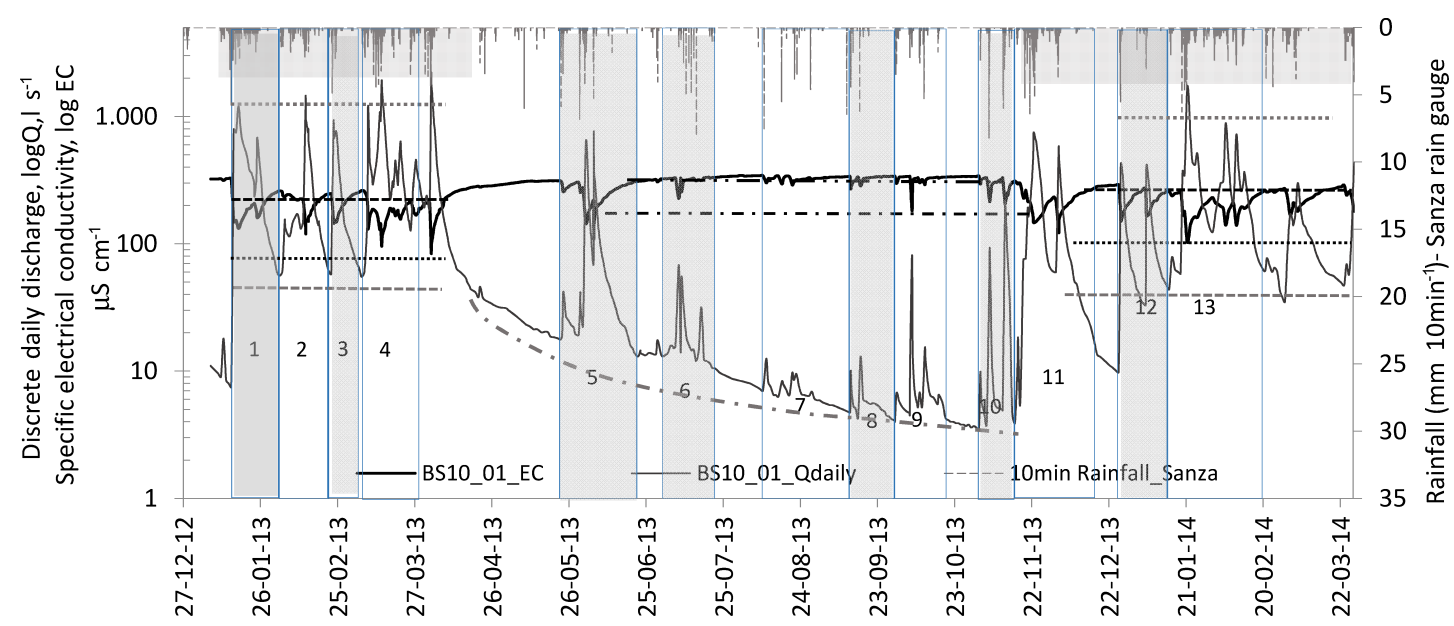

Figure 2. Plot of the hydro-chemograph data set recorded at the main monitoring station (BS16_01) and the 10 min rainfall plot at the Sanza rain gauge (from Cuomo and Guida, 2016). Legend: numbers indicate the selected events; horizontal lines are representative of the reference parameter ranges; black dashed-double dot lines indicate EC maxima in the dry period; the black dashed-dot line represents EC minimum during the dry period; the black dashed line indicates EC maxima in the wet period; the black dotted line represents an EC minimum in the wet period; the gray dashed line indicates the $Q$ minima in the wet period; the gray dotted line indicates the average $Q$ maximum in the wet period; finally, the gray dashed-dot curve indicates the theoretical annual baseflow curve of the catchment during the period under consideration.

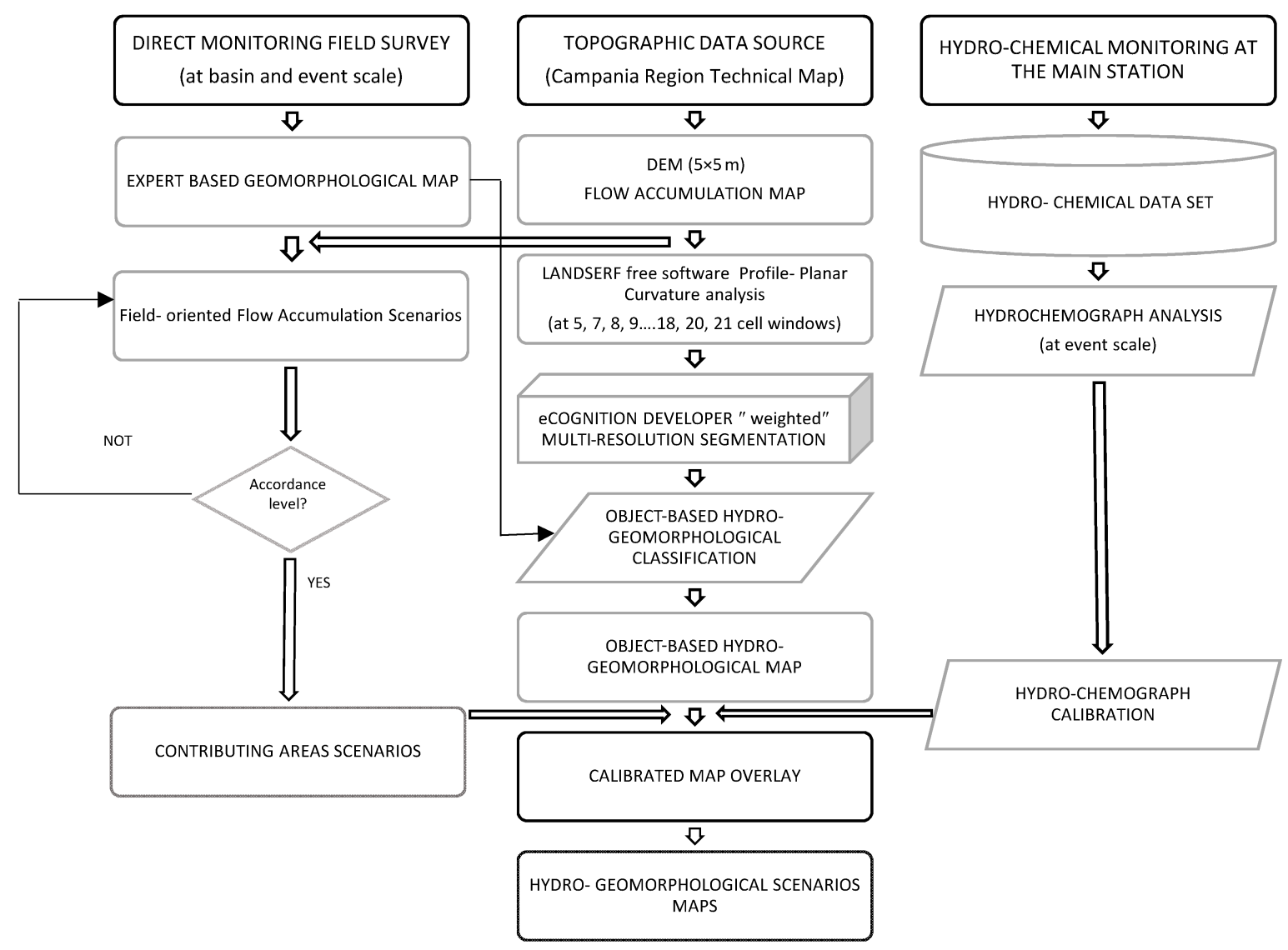

Figure 3. Flow chart procedure for identifying contributing areas. 

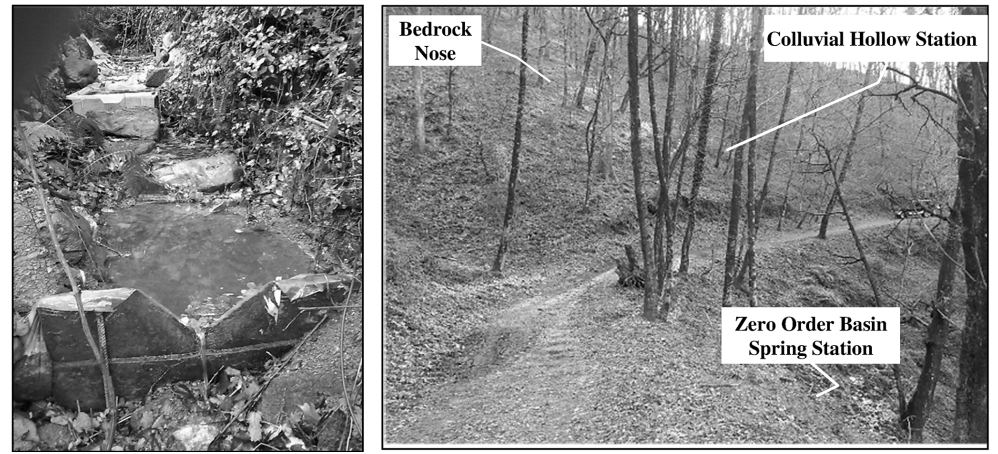

Figure 4. (a) The V-notch weir at the BS16_01_01dx and (b) stations.

In the following sections, an integrated procedure is proposed that uses simple geomorphometric tools to take into account various hydrological and geomorphological factors that cause time-space runoff variability in the catchment case study.

The flowchart in Fig. 3 shows the three integrated approaches used in the application.

The first approach on the left-hand side highlights the expert-based activities by geomorphological surveys and direct monitoring carried out at basin scale before and during the application event and the derivation of traditional, handdrawn, expert-based geomorphological maps. The fieldoriented flow accumulation scenarios were obtained from data collected at the control points (Fig. 1) for each event time step (five time steps) and each hydro-geomorphotype and by using the flow accumulation map derived from the second step described below. The expert-based activities are illustrated in Sect. 3.1. The second approach (see the flowchart in the center) shows the geomorphometric routine activities carried out during the application, as illustrated in Sect. 3.2. Starting from the topographic data source, a hydrologically corrected DEM was obtained and the log of the flow accumulation map was derived, which was reclassified in the first approach in order to obtain the best agreement with the field evidence highlighted during the storm event at each hydro-geomorphotype. The field-oriented flow accumulation maps were obtained as a proxy for the contributing area scenarios. As better explained in Sect. 3.2, after five elaboration steps, the geomorphometric analysis provided us with the object-based hydro-geomorphological map of the catchment, quantitatively defining the spatial extension of the basic hydro-geomorphotypes. The hydro-geomorphotype map was calibrated with the hydro-chemical analysis illustrated in Sect. 3.3 and was then overlaid with the five contributing area scenarios, thus obtaining the final hydro-geomorphological scenarios maps.

\subsection{Direct survey on the catchment during a storm event}

Before and during the storm event in the period from 29 to 31 January 2015, one of the authors and field collaborators carried out direct field surveys by measuring EC and, wherever possible, the $Q$ parameters on the control points in Fig. 1, and repeated them at each time step of the storm event. The pre-event conditions were detected at 17:15 on 29 January 2015 by carrying out systematic surveys and taking measurements from the main stream and secondary channel stations (Fig. 4a), where only groundwater feeds the discharge along the riparian corridors. After the beginning of rainfall, measurements were taken from 07:20 to 09:10 on $30 \mathrm{Jan}$ uary 2015 at the zero-order basin springs and hollow stations (Fig. 4b), where the soil became increasingly saturated and contemporarily new water was added from the riparian corridor downstream.

During the storm event, repeated measurements were taken at the same control points from 11:30 to 13:00 detecting direct runoff (Fig. 5a) and soil pipe contribution (Fig. 5b).

Figure 6a shows the hydro-chemograph of the storm event recorded at the main station and cumulative rainfall measured at the nearest rain gauge station. On the plot, the phases of hydrological response in the catchment were determined by means of the progressive runoff generation activation, identified with the above-mentioned field measurements. In Fig. 6b, the hysteretic $Q$-EC cycle (Cuomo and Guida, 2016) of the event demonstrates homogeneity in hydro-chemical response in the rising and recession limbs. At 20:00 on 29 January 2015, the field measurements at piezometers and QsEC values (approximately $60 \mathrm{~L} \mathrm{~s}^{-1}$ and $240 \mu \mathrm{S}^{-1}$ ) recorded at the main station were typical of pre-event conditions occurring during the wet period, as found by Cuomo and Guida (2016). After it started raining, in addition to the direct rainfall in the main streamflow, the contribution from groundwater ridging along the riparian corridor and floodplain began to feed the total discharge. The contribution area expands with continual rainfall and excess saturation runoff is progressively added to the discharge from the col- 

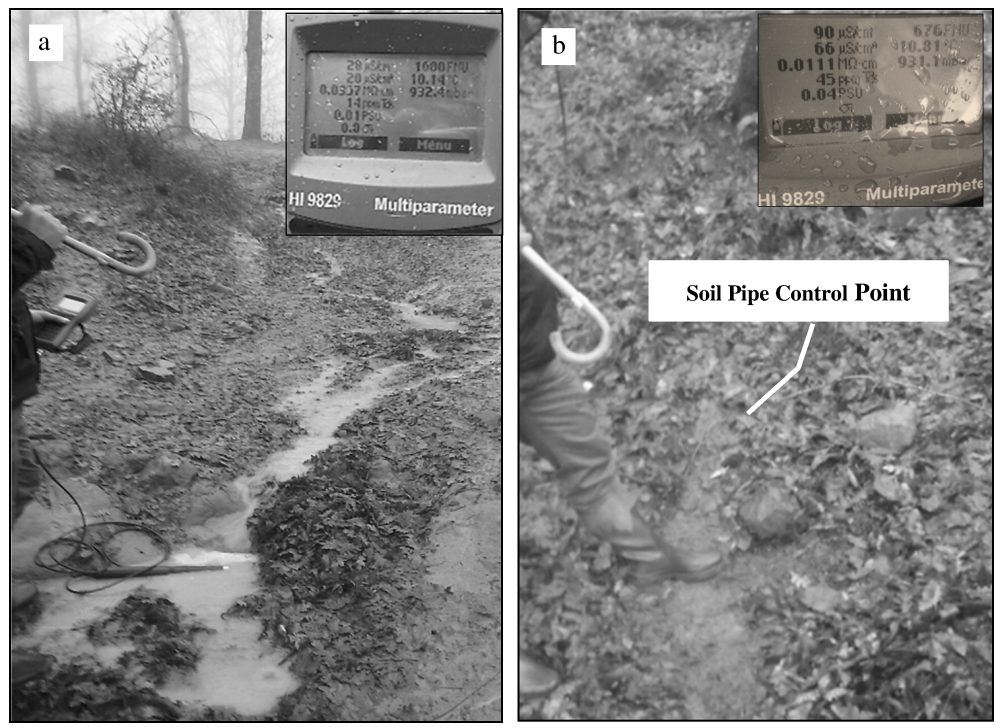

Figure 5. Measurements at 12:00 in the dirt road point controls (a) and the soil pipe (b) with respective EC values.
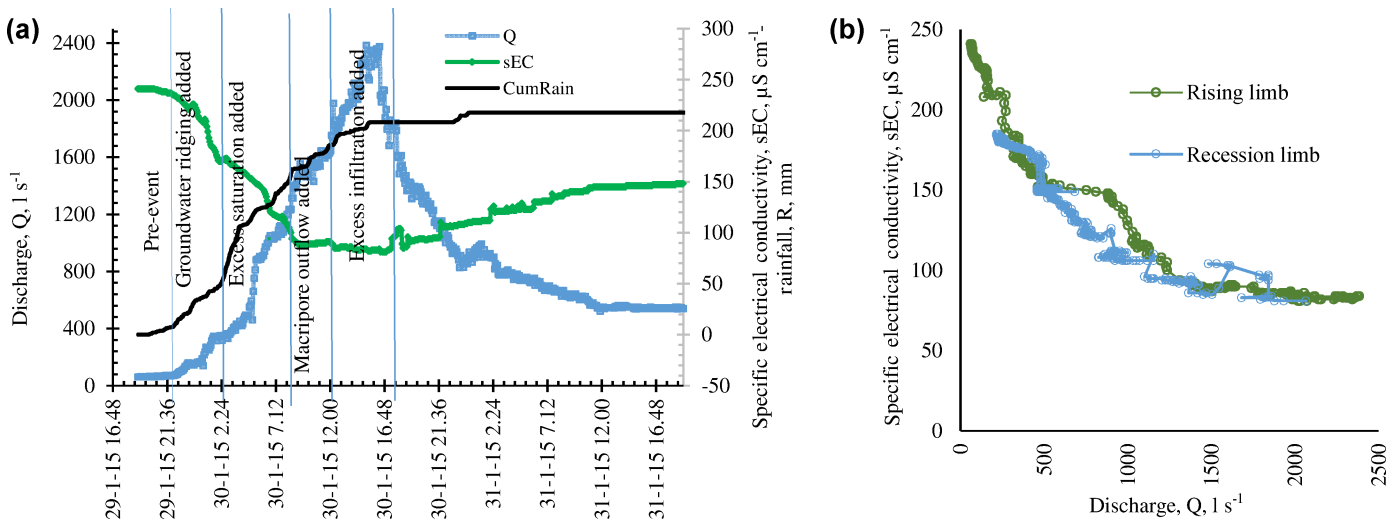

Figure 6. (a) Hydro-chemograph plot of the 29-31 January 2015 storm event and related hydro-geomorphological phases, during which the runoff components are progressively added, according to Table 3; (b) $Q$-EC hysteretic cycle of the storm event.

luvial hollows, reaching approximately $Q=1000 \mathrm{~L} \mathrm{~s}^{-1}$ and $\mathrm{sEC}=100-120 \mu \mathrm{S}^{-1}$. In addition to these values, firstly the macropore contribution is added. Finally excess infiltration runoff from the saturated areas becomes dominant, which progressively increases the discharge, reaching asymptotical $\mathrm{sEC}=80 \mu \mathrm{S}^{-1}$ values.

In order to obtain the contributing area scenarios, the flow accumulation map by means of the SAGA module implemented in QGIS was generated. More precisely, the log values of the flow accumulation map were reclassified according to the actual conditions observed in streamflow and each hydro-geomorphotype during five different scenarios that occurred during the training storm event. The final contributing area scenario map shows the best agreement between the reclassified log values of the flow accumulation map and the field evidence.

\subsection{Object-based hydro-geomorphological mapping}

In order to quantitatively define the runoff source areas, an object-based hydro-geomorphological map of the catchment was created using an original, automatic spatial analysis procedure. Starting from the Campania Region Technical Map at $1: 5000$ scale (CTR), a vector map providing elevation values, a digital elevation model (DEM) with a $5 \mathrm{~m}$ cell size was obtained by means of the Topo-To-Raster tool (TOPOGRID) in ArcGIS. This algorithm provides an interpolation method specifically designed for creating hydrologically corrected DEMs. Moreover, further spurious sinks have been removed by means of the Fill tool. In the scientific literature some methods are known for a more suitable grid resolution (Hengl, 2006) based on the properties of the input data (i.e., complexity of the land surface), but the grid spacing used appeared to be suitable for hydro-geomorphological 
applications since it follows the general rule that it should be adequately sufficient at the local hillslope scale, marking the transition in process dominance from hill slope to channel (Peckham, 2009). This DEM was used for creating an "object-based" hydro-geomorphological map that was obtained with a step-by-step rule set. During the first step, a geomorphometric analysis was performed by calculating plan and profile curvatures at increasing cell window sizes: 5, 7, $9,11,13,15,17,19$ and 21 cells. The multiscale analysis of curvatures was performed with Landserf free GIS software, thus obtaining a raster layer for each geomorphometric calculation.

During the second step the best agreement with expertbased geomorphological mapping was achieved with eCognition Developer software by means of an original multiresolution segmentation algorithm, using appropriate landsurface parameters.

The multiresolution segmentation algorithm merges spatially contiguous pixels or cells into "image objects" (segments) based on local homogeneity criteria of the input parameters. These segments, bounded by discontinuities in the input variables, are then used as building blocks in the classification, according to attributes such as average values of input variables, shape indexes, and topological relations of segments (Dragut et al., 2013).

More precisely, the morphometric parameters obtained during the previous step (plan and profile curvatures at various cell windows) are used with a proportional increased weight to the increasing cell window size for each raster layer (Table 1); sine and cosine of aspect were also used as input parameters. We did not consider the slope gradient since it is quite constant except for the valley bottom and hilltop and did not provide us with additional information for the segmentation procedure.

Other settings used for this algorithm are scale 7, shape 0.0002 , and compactness 0.0002 .

During this procedure, the segments obtained were compared to the expert-based geomorphological mapping by using the target-training procedure proposed in Guida et al. (2015) (Fig. 7a).

The image objects obtained from the segmentation are shown in Fig. 7b.

In the third step, the objects obtained during the previous step were classified. The classification procedure was carried out according to the criteria proposed by Hennrich et al. (1999), whose conceptual background was the "landscape catena" (Conacher and Dalrymple, 1977), which combines surface form and pedo-hydro-geomorphological processes at hillslope scale.

The classification was based on the sum of the planimetric curvatures that were re-classified according to the threshold values listed in Table 2 . The interval values listed in Table 2 were achieved by a supervised classification. By only using the plane curvature sum computed with different window sizes, we were able to obtain an object-based hydro-
Table 1. Weights assigned to each layer implemented in the eCognition developer software for the multiresolution segmentation algorithm.

\begin{tabular}{ll}
\hline Layer (cell window) & Weight \\
\hline Plan curv (5) & 1 \\
Plan curv (7) & 2 \\
Plan curv (9) & 3 \\
Plan curv (11) & 4 \\
Plan curv (13) & 5 \\
Plancurv (15) & 6 \\
Plan curv (17) & 7 \\
Plan curv (19) & 8 \\
Plan curv (21) & 9 \\
Prof curv (5) & 1 \\
Prof curv (7) & 2 \\
Prof curv (9) & 3 \\
Prof curv (11) & 4 \\
Prof curv (13) & 5 \\
Prof curv (15) & 6 \\
Prof curv (17) & 7 \\
Prof curv (19) & 8 \\
Prof curv (21) & 9 \\
Aspect Cos & 10 \\
Aspect Sin & 10 \\
\hline
\end{tabular}

geomorphological map (Fig. 7c), which was in good agreement with the expert-based geomorphological map.

Finally, a spatial statistical analysis was performed on the object-based hydro-geomorphotype map (Fig. 7c) and the five contributing area scenarios maps in order to evaluate their spatial relationships for the training storm event that occurred in January 2015 (Fig. 6). The application at the storm event timescale is described in the next section.

\subsection{Dynamic hydro-chemograph separation}

In order to understand the runoff generation that occurs during storm events for each period (wet/dry), we used the $Q$-EC relationship data analysis proposed by Cuomo and Guida (2013) and Guida and Cuomo (2014) due to the good agreement between the hydro-chemograph separation and the hydrograph filtering comparative procedure introduced by Longobardi et al. (2014, 2016). Moreover, Cuomo and Guida (2016) subsequently proposed a modified mass balance procedure based on a "step-like", recursive, twocomponent hydrograph separation for the Ciciriello catchment. The authors assigned a correspondent mechanism of runoff generation to each component and the $Q$-EC threshold values for each mechanism in that contributing area started to enlarge and expand. 

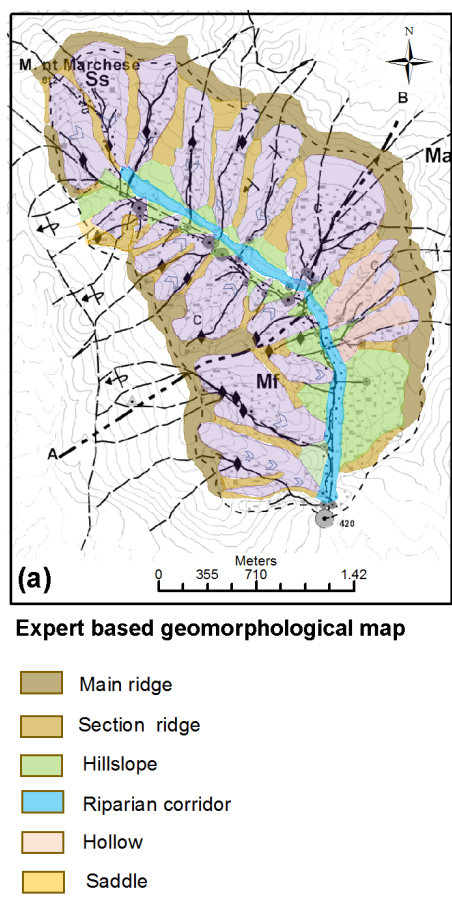
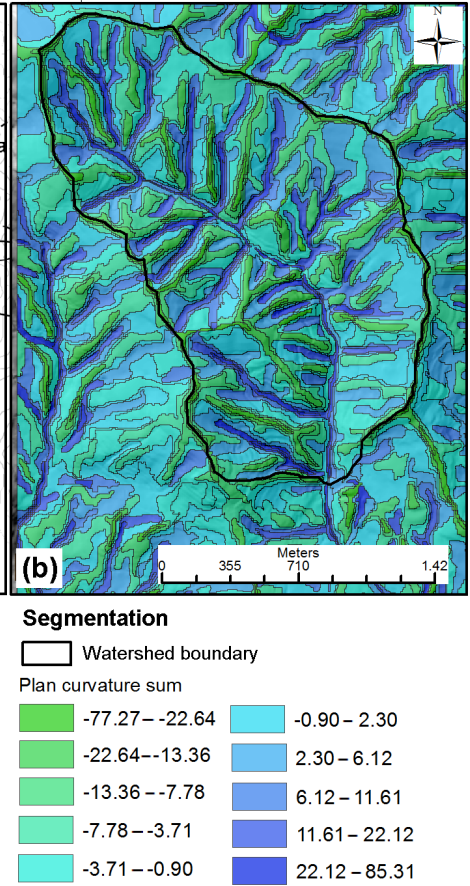

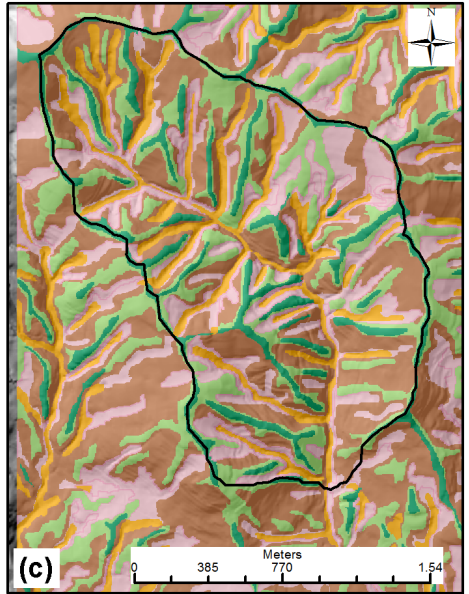

Hydro-geomorphotypes

$\square$ Watershed boundary

Ridge

Nose

Hillslope

Hollow

Riparian corridor

Figure 7. (a) Expert-based hydro-geomorphological map; (b) multiresolution segmentation map; (c) object-based hydro-geomorphological map obtained by classifying the multiresolution segmentation map using the plan curvature sum only.

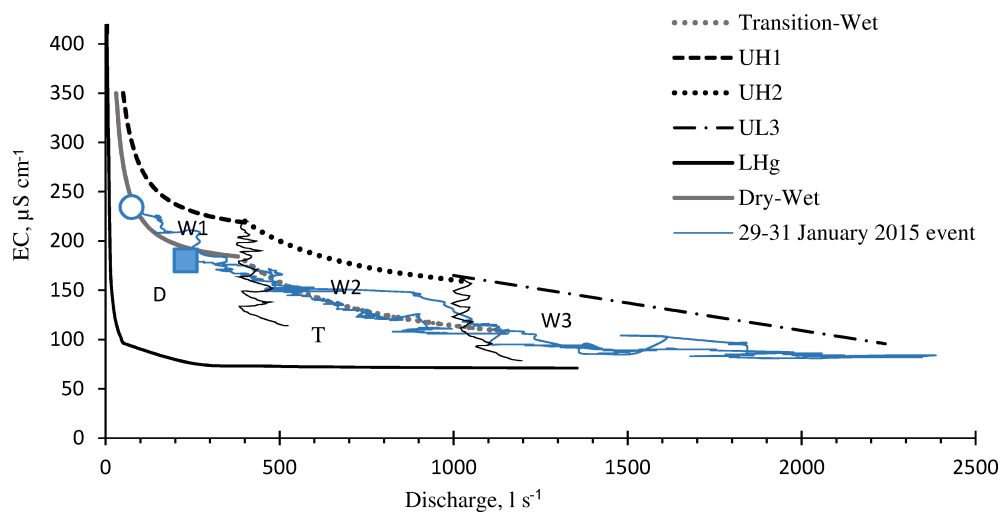

Figure 8. Delimitation of the five inner fields that define the limits of seasonal response of the catchment (modified from Cuomo and Guida, 2016) and, in blue, the hysteretic cycle of the study event, from its beginning (blue circle) to its end (blue square). Legend: UH1 and W1, upper hyperbolic curve 1 and wet area 1, respectively (typical of the $Q$-EC mixed value of groundwater and groundwater ridging); UH2 and W2, upper hyperbolic curve 2 and wet area 2, respectively (typical of the $Q$-EC mixed value of groundwater, groundwater ridging and subsurface flow); UL3 and W3, upper linear curve and wet area 3, respectively, typical of the $Q$-EC mixed value of groundwater, groundwater ridging subsurface flow and direct runoff; $\mathrm{LHg}$, lower hyperbolic curve typical of the $Q$-EC response when direct runoff is suddenly added to the groundwater following the heavy showers that occurred during the dry period; $D$, the dry area where the $Q$-EC typical of a dry fall for which only the groundwater flow feeds the streamflow; $T$, transition area, where the $Q$-EC typical values of a dry-wet or wet-dry fall, when the groundwater flows, groundwater ridging and soil pipe feed the streamflow.

In this study, these values were used for each phase of the field survey in order to verify the correspondence between the end-member hydro-chemograph signature proposed by Cuomo and Guida $(2013,2016)$ and Guida and Cuomo (2014), and the starting runoff contributing area.
Cuomo and Guida (2016) adopted the daily data set illustrated in Sect. 2 (Fig. 2) using the end-members that the authors measured at specific stormflow components by carrying out direct surveys and taking piezometric measurements. They obtained three upper boundary curves and one lower boundary curve (Fig. 8), each of them representing a spe- 
Table 2. Geomorphometric classification, geomorphological correspondence, hydro-geomorphotype definition and hydro-geomorphological behavior for each hydro-geomorphotype.

\begin{tabular}{|c|c|c|c|c|}
\hline $\begin{array}{l}\text { Sum of plan curvature } \\
\text { class (SPC) }\end{array}$ & $\begin{array}{l}\text { Geomorphometric } \\
\text { parameters and to- } \\
\text { pographic position }\end{array}$ & $\begin{array}{l}\text { Landform, com- } \\
\text { ponent or element } \\
\text { (Dramis et al., } \\
\text { 2011) }\end{array}$ & $\begin{array}{l}\text { Hydro- } \\
\text { geomorphotype } \\
\text { (HGT in Cuomo, } \\
\text { 2012) }\end{array}$ & $\begin{array}{l}\text { Hydro-geomorphological } \\
\text { behavior }\end{array}$ \\
\hline $\mathrm{SPC}<-13.4$ & $\begin{array}{l}\text { Convex, divergent } \\
\text { flow-like, upslope }\end{array}$ & $\begin{array}{l}\text { Upland, summit, } \\
\text { peak, crest }\end{array}$ & Ridge & $\begin{array}{l}\text { Groundwater recharge on } \\
\text { bare bedrock and dominant } \\
\text { excess infiltration runoff af- } \\
\text { ter storm }\end{array}$ \\
\hline$-13.4>=\mathrm{SPC}<-3.76$ & $\begin{array}{l}\text { Light convex- } \\
\text { divergent flow-like, } \\
\text { up to mid-slope }\end{array}$ & $\begin{array}{l}\text { Shoulder, side } \\
\text { slope }\end{array}$ & Nose & $\begin{array}{l}\text { Shallow soil, groundwater } \\
\text { recharge area, prevalently } \\
\text { excess infiltration runoff }\end{array}$ \\
\hline$-3.76>=\mathrm{SPC}<2.3$ & $\begin{array}{l}\text { Light convex- } \\
\text { planar, parallel } \\
\text { flow-like, midslope }\end{array}$ & $\begin{array}{l}\text { Scarps, back } \\
\text { slope, foot slope, } \\
\text { wash slope, talus, }\end{array}$ & Hillslope & $\begin{array}{l}\text { Debris, deep soil, shallow } \\
\text { aquifer, excess } \\
\text { saturation excess and } \\
\text { sub-surficial runoff }\end{array}$ \\
\hline $2.3>=\mathrm{SPC}<11.6$ & $\begin{array}{l}\text { Planar to light con- } \\
\text { cave, convergent } \\
\text { flow-like, upslope }\end{array}$ & Glen, swallet, scar & Hollow & $\begin{array}{l}\text { Deep soil, shallow aquifer, } \\
\text { prevalently excess satura- } \\
\text { tion, delayed runoff pro- } \\
\text { duction }\end{array}$ \\
\hline $\mathrm{SPC}=>11.6$ & $\begin{array}{l}\text { Concave, con- } \\
\text { vergent mid- to } \\
\text { down-slope }\end{array}$ & $\begin{array}{l}\text { V-shaped stream, } \\
\text { gully, bank, stream } \\
\text { bed }\end{array}$ & Riparian corridor & $\begin{array}{l}\text { Shallow soil, groundwater } \\
\text { discharge, prevalently sub- } \\
\text { surface, delayed return flow } \\
\text { and groundwater ridging }\end{array}$ \\
\hline
\end{tabular}

Table 3. Hydro-chemical parameter range, distinctive for the wet $(W)$, dry $(D)$ and transition $(T)$ period events. Legend: GW is for groundwater, SSF is for subsurface flow, and DR is the direct runoff (modified from Guida and Cuomo, 2016).

\begin{tabular}{|c|c|c|c|c|}
\hline Field & Processes and contributing areas & $\begin{array}{c}\mathrm{EC}_{\text {quick }} \text { range } \\
\left(\mathrm{mS} \mathrm{cm}^{-1}\right)\end{array}$ & $\begin{array}{c}\mathrm{EC}_{\text {slow }} \text { range } \\
\left(\mathrm{mS} \mathrm{cm}^{-1}\right)\end{array}$ & $\begin{array}{c}Q_{\text {threshold }} \\
\left(\mathrm{L} \mathrm{s}^{-1}\right)\end{array}$ \\
\hline \multirow{2}{*}{ W1 } & GW from bedrock deep and perched aquifer & & $250-300$ & $30-50$ \\
\hline & $\mathrm{GW}+\mathrm{GW}_{\text {ridging }}$ added from riparian corridor & $200-220$ & & 400 \\
\hline \multirow[t]{2}{*}{ W2 } & $\mathrm{GW}+\mathrm{GW}_{\text {ridging }}$ along the riparian corridor & & $200-220$ & \\
\hline & $\mathrm{GW}+\mathrm{GW}_{\text {ridging }}+\mathrm{SSF}$ added from colluvial hollow & $120-180$ & & 1000 \\
\hline \multirow[t]{2}{*}{ W3 } & $\mathrm{GW}+\mathrm{GW}_{\text {ridging }}+\mathrm{SSF}$ & & $120-180$ & 1000 \\
\hline & $\mathrm{GW}+\mathrm{GW}_{\text {ridging }}+\mathrm{SSF}+\mathrm{DR}$ added from soil pipe & $70-180$ & & $\gg 1000$ \\
\hline \multirow[t]{2}{*}{$D$} & GW & & $320-350$ & $3-5$ \\
\hline & $\mathrm{GW}+\mathrm{GW}_{\text {ridging }}$ & $100-180$ & & 400 \\
\hline \multirow[t]{2}{*}{$T$} & $\mathrm{GW}+\mathrm{GW}_{\text {ridging }}$ & & $100-180$ & 400 \\
\hline & $\mathrm{GW}+\mathrm{GW}_{\text {ridging }}+\mathrm{DR}$ added from soil pipes & $100-120$ & & \\
\hline
\end{tabular}

cific mechanism, source area and timing of runoff production. The lower hyperbolic curve ( $\mathrm{LHg}$ ) delimits all the $Q$ EC values recorded during the dry period. The upper hyperbolic (UH) curves delimit the $Q$-EC values that are typical of groundwater and groundwater ridging for the UH1 curves. The second upper hyperbolic curves (UH2) start when the UH1 reaches its horizontal asymptote and the subsurface mechanism starts, following which the upper linear curve (UL) starts when the direct runoff and soil pipe mixes with the previous components. The estimated intersection points between the three upper consecutive curves are the $Q$-EC threshold values for which another mechanism starts and hydro-dynamically interacts with the previous mechanism. In this way, the waters join together before reaching the streamflow. Subsequently, the authors carried out the same procedure on the 13 storm events shown in Fig. 2. Events nos. 1, 2, 3, 4, 10, 11, 12, and 13 were assigned to the wet recharging period, while event nos. 5, 6, 7, 
(a)

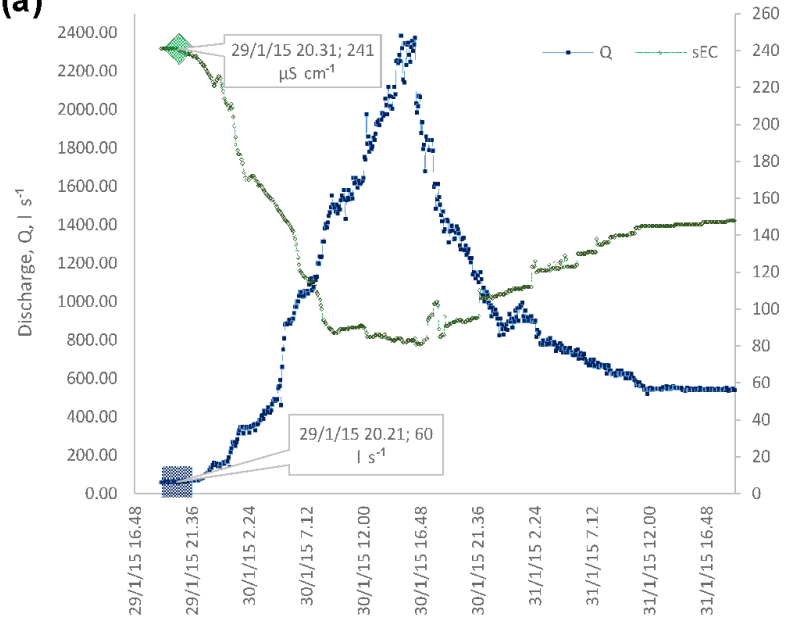

(b)

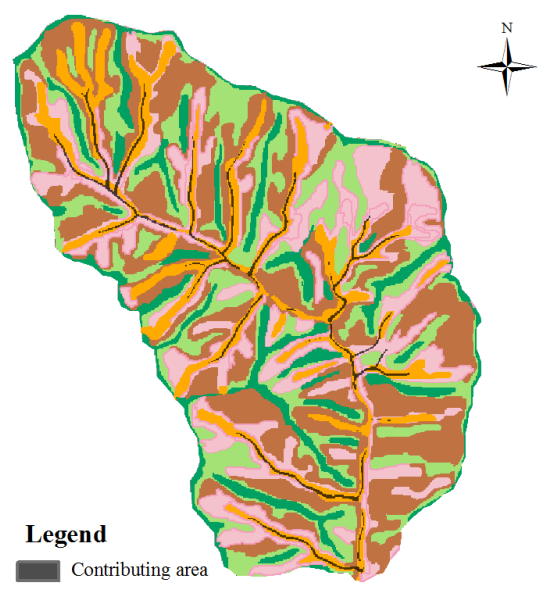

Figure 9. (a) Pre-event hydro-chemograph conditions, just before the storm event, with $Q=60 \mathrm{~L} \mathrm{~s}^{-1}$, filled blue square, and EC $=240 \mu \mathrm{S}^{-1}$, filled green diamond, (b) scenarios corresponding to groundwater and decreasing groundwater ridging contribution to streamflow running exclusively along the riparian corridor and main streamflow.

8 , and 9 were assigned to the dry discharging period. Moreover, the $Q$-EC relationship highlights three different types of hydrologic behavior occurring in the three hydrologic periods: wet $(W)$, dry $(D)$ and transition $(T)$. In this way, the boundary curves between the dry-wet and wet-transition events were obtained in order to define further inner fields. Figure 8 shows a typical "threshold hydro-geomorphological system", where each source runoff remains independent during low magnitude events but interacts physically and functionally with other sources at higher event magnitudes, thus inducing superposed hydrological mechanisms and complex hydro-chemical water mixing by dilution, dispersion and diffusion. By identifying these five areas with respect to the hydrologic behavior of the catchment, it was possible to carry out the analyses for delimiting the contributing area in the next section using the thresholds listed in Table 3.

By including the hysteretic cycle of the 29-31 January 2015 study event in the plot of Fig. 8, the hydrogeomorphological response (see Supplement data) can be classified as typical for a wet period that occurred after a short transition period during which the aquifer began to fill and groundwater ridging decreased progressively. As expected, during the event all the runoff components were progressively activated when the $Q$-EC threshold values for each started. Consequently, the contributing areas enlarged the floodplain upslope, the riparian corridors and the zeroorder basins upstream, encompassing the $Q$-EC value ranges listed in Table 3. These values were verified during the field survey reported in Sect. 3.1 and used for the hydrogeomorphological analyses of the next section.

\section{Results}

For the storm study, the variability of the contributing area was obtained by combining the hydro-chemical procedure and the object-based hydro-geomorphotype map. As a result of this analysis, contributing area space-time variability was obtained for the selected storm event by combining hydrochemical procedure outcomes, the hydro-geomorphotype map and the contributing area scenarios.

On the right-hand side of Figs. 9-13, hydro-chemograph evolution at the five time steps discussed in Fig. 6a is illustrated, while on the left-hand side of Figs. 9-13, we can see the progressive expanding contributing areas shown on the hydro-geomorphotype map. Specific observations are provided in the figure captions and the corresponding values for the increasing contributing area are listed in Table 4.

Figure 9 shows pre-event conditions, when only the baseflow and the decreasing groundwater ridging from previous events were activated.

By plotting the $S$ vs. $Q$ data from Table 3 on a normal plot, we can follow the pattern of the progressive involvement of the runoff components as specific contributing areas in streamflow (Fig. 14).

In our case, a positive exponential function was obtained for each hydro-geomorphotype curve as shown in Fig. 14. This approach is similar to the calculations proposed by Latron and Gallart (2007), but in this case the contributing area is calculated according to the baseflow component as well as the other components related to hydro-geomorphotypes. All the curves have a general exponential pattern (Eq. 1):

$S(t)=S_{0} e^{a Q(t)}$,

where $S(t)$ is the total contribution area at instant $t, \mathrm{~S}_{0}$ the initial contribution area, $e^{a}$ is a constant for a specific com- 
(a)

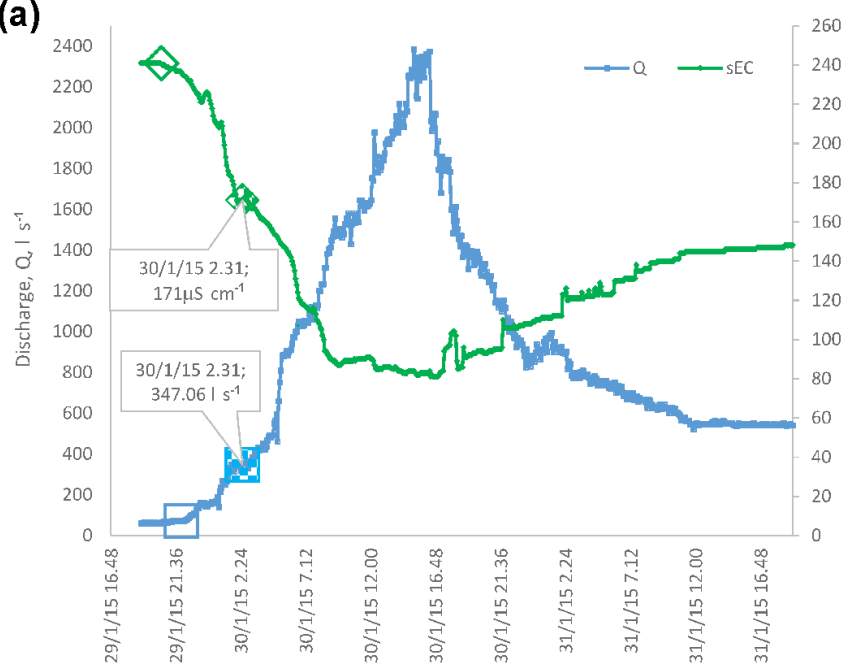

(b)

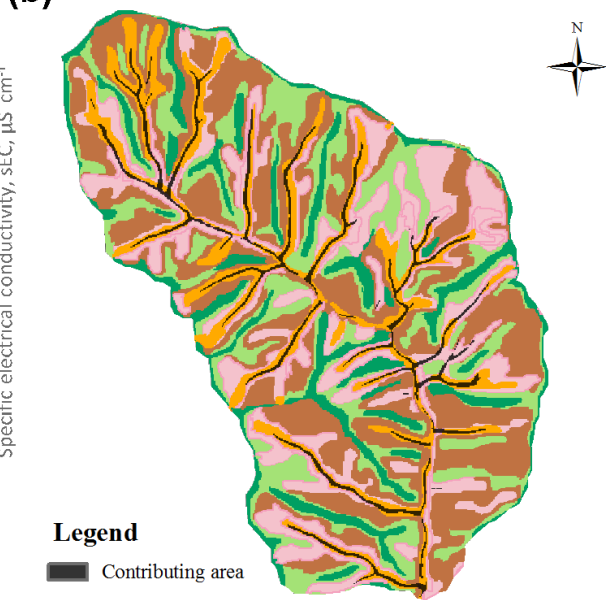

Figure 10. Initial hydro-chemograph conditions just after the beginning of the storm event, with approximately $Q=350 \mathrm{~L} \mathrm{~s}^{-1}$, filled blue square, and approximately $\mathrm{EC}=170 \mu \mathrm{S}^{-1}$, filled green diamond, (b) scenarios corresponding to increasing groundwater ridging and initial saturation excess contributions to streamflow. The first occurs along the riparian corridor, and the second at the apical transient channels just downstream from the colluvial hollows, respectively.

(a)

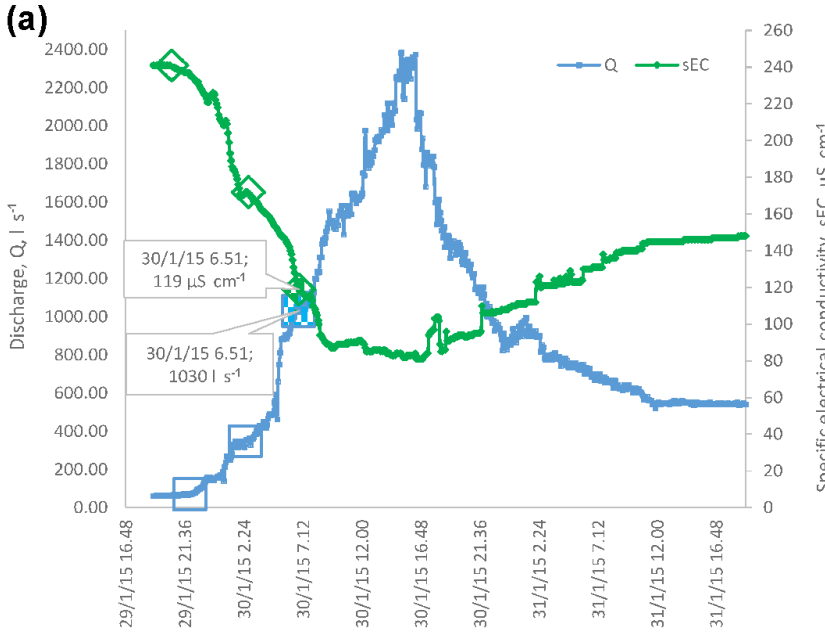

(b)

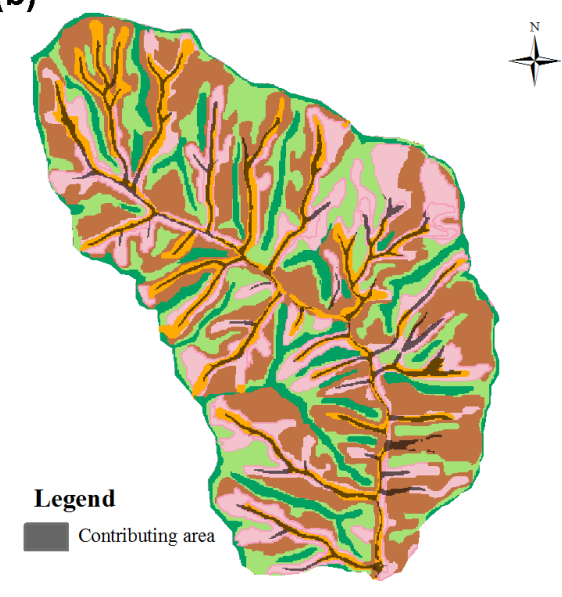

Figure 11. (a) Progressive hydro-chemograph conditions after approximately $60 \mathrm{~mm}$ of rainfall, with approximately $Q=1000 \mathrm{~L} \mathrm{~s}{ }^{-1}$, filled blue square, and approximately $\mathrm{EC}=120 \mu \mathrm{S}^{-1}$, filled green diamond, (b) scenarios corresponding to a full saturation excess contribution to streamflow along the riparian corridor and at transient channels within the colluvial hollows, respectively.

ponent considered, and $Q(t)$ is the discharge at the time of $\mathrm{S}(\mathrm{t})$.

Equation (1) can be re-written as

$\log S(t)=a Q(t)+\log S_{0}$.

The riparian contribution trend is higher than the hollow and hillslope trends for a discharge from 50 to $1000 \mathrm{~L} \mathrm{~s}^{-1}$, but the specific hollow and hillslope contributing areas progressively reach the same values as the riparian corridor in the event of high discharge. In fact, a slight increase in the discharge from the riparian corridor was observed during the event $(a=0.0012)$. On comparing the behavior of the hollow and the hillslope, it seems that the hollow has a higher contributing area for lower discharge (from 50 to $600 \mathrm{~L} \mathrm{~s}^{-1}$ ) than the hillslope contributing area (Fig. 14). However, after the discharge increased, the two hydro-geomorphotypes reached the same percentages as the contributing areas $\left(\mathrm{A}_{2}\right.$ in Table 4). A lower contribution originated from the nose, whose contributing area is not influenced by the discharge until it reaches $1000 \mathrm{~L} \mathrm{~s}^{-1}$, after which it increases rapidly $(a=0.0041)$. 
(a)

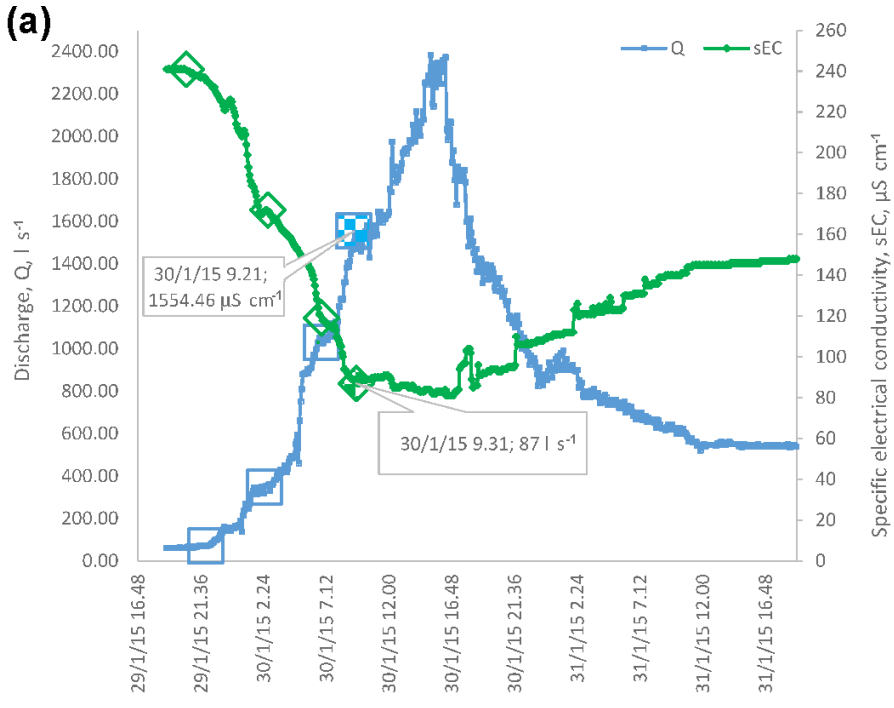

(b)

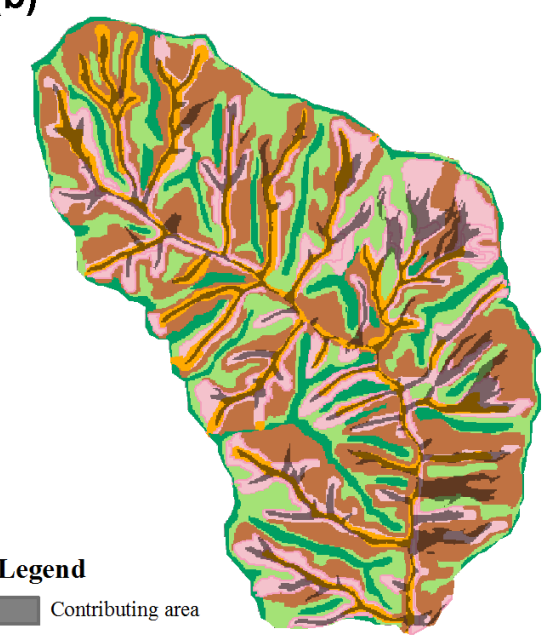

Figure 12. Advanced hydro-chemograph conditions, after approximately $80 \mathrm{~mm}$ of rainfall, with approximately $Q=1550 \mathrm{Ls}-1$, filled blue square and approximately $\mathrm{EC}=90 \mu \mathrm{S}^{-1}$, filled green diamond, (b) scenarios corresponding to a full saturation excess contribution to streamflow along the riparian corridor and the whole colluvial hollows, respectively.

(a)

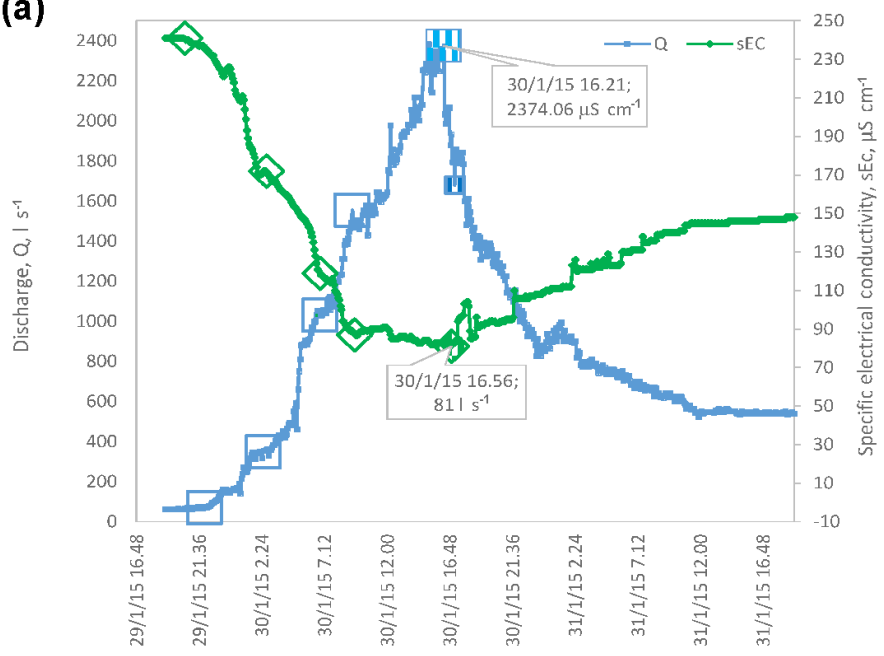

(b)

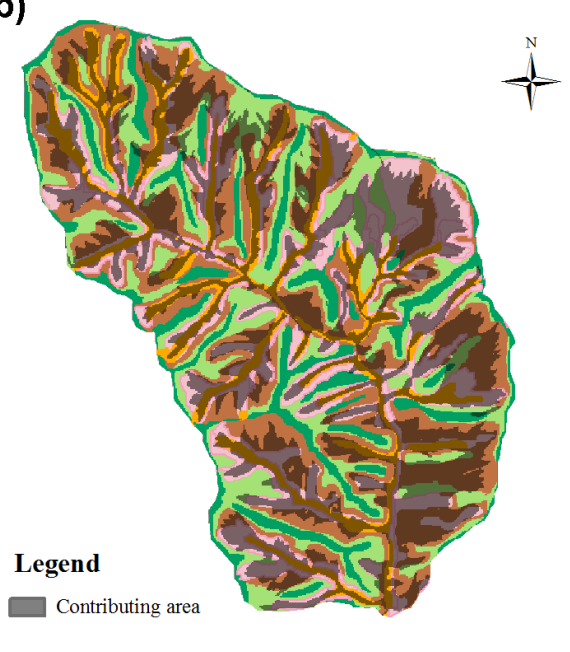

Figure 13. Final hydro-chemograph conditions, after approximately $100 \mathrm{~mm}$ of rainfall inducing a peak discharge of approximately $Q=2400 \mathrm{~L} \mathrm{~s}^{-1}$, filled blue square, and about $\mathrm{EC}=80 \mu \mathrm{S}^{-1}$, filled green diamond, (b) corresponding both to full saturation excess contributions to streamflow from the riparian corridor and colluvial hollows, as well as to macropore (soil pipe and fracture) and excess infiltration on noses and partially on the ridges, respectively.

Since 1970 authors have studied the relationships between the contributing area and the baseflow discharge (Fig. 15a). In fact, Ambroise (1986), Myrabo (1986) and Latron (1990) found good relationships for some catchments in which the increasing rate of the relative saturated area decreases with the increase in a specific discharge.

Dunne et al. (1975) observed that an increase in the saturated area leads to an increase in the discharge. More recently the same relationship was observed by MartinezFernandez (2005). Latron and Gallarat (2007) found a lin- ear relationship between the specific discharge and the extent of the contributing area. The authors believe that, unlike the other catchments, the linear trend could be reasonable since the saturation of the catchment under study is not conditioned by its topography.

For the Ciciriello catchment we examined the relationships between the percentage of the contributing area (A1 in Table 4) and the specific discharge for each hydrogeomorphotype considered (Fig. 15b), and we believe that this trend is similar to that observed by Dunne et al. (1975). 


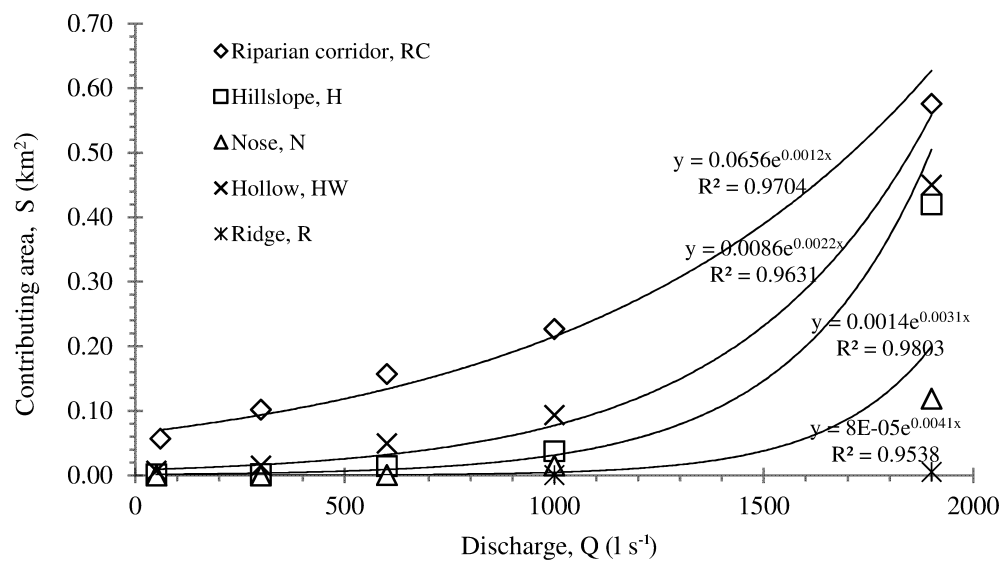

Figure 14. Plot of the contributing area vs. discharge from data in Table 3.

(a)

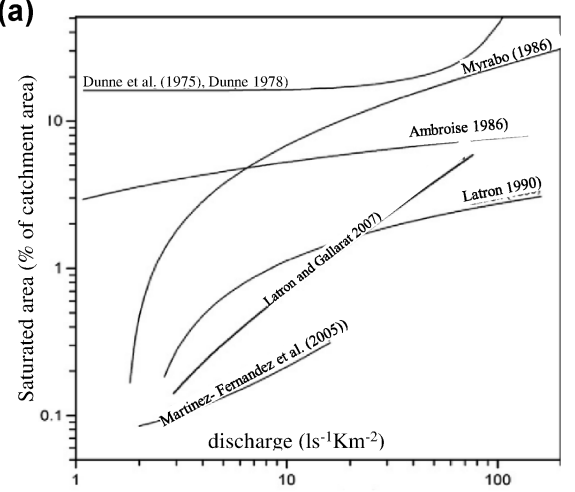

(b)

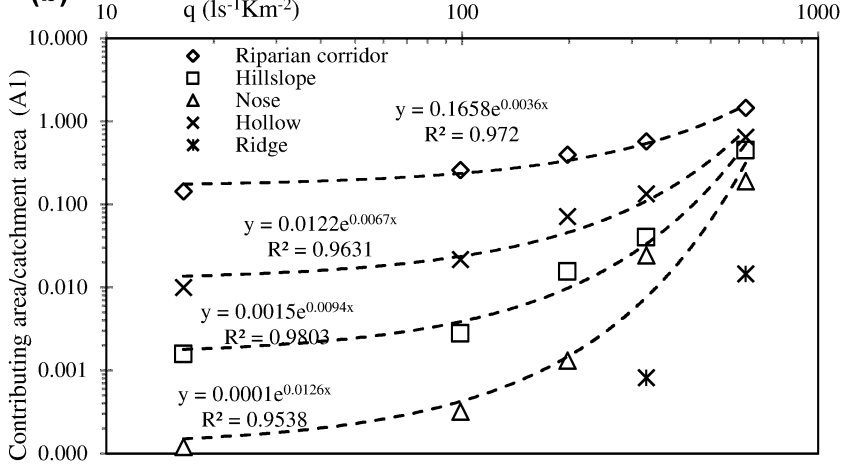

Figure 15. (a) Relationship between the total extent of contributing saturated areas and the baseflow discharge in several small (less than $10 \mathrm{~km}^{2}$ ) catchments (modified from Latron and Gallarat, 2007); (b) relationship between the contributing areas and the specific discharge for each hydro-geomorphotype of the Ciciriello catchment.

When a low discharge occurs, the riparian corridor slowly contributes to the increasing discharge, and only for $q=100 \mathrm{~L} \mathrm{~s}^{-1} \mathrm{~km}^{-2}$ does this hydro-geomorphotype widen its contributing areas. Fig. 15 shows the increase in faster contributing areas for hollow, hillslope and nose at specific discharges $q=300,200$ and $100 \mathrm{~L} \mathrm{~s}^{-1} \mathrm{~km}^{-2}$, respectively. In this case these $q$ values are considered as the $q$ threshold values for activating runoff mechanisms.

There is an evident anomaly regarding the riparian corridor, as it shows a percentage of contributing area over $100 \%$. In our opinion, this result is due to a DEM resolution and the riparian corridor must be carefully defined due to the possible overlap with other hydro-geomorphotypes, especially the hollows. In Fig. 15 it is important to note the intersection between all the curves at high $q$ values. In our opinion, it shows the interaction between all the runoff mechanisms occurring in the catchment during high-magnitude events before reaching the stream, as assumed by Cuomo and Guida (2016).

One of the most interesting results of this study is the experimental confirmation of the pre-event water contributions to streamflow by the rapid mobilization of the capillary fringe inducing groundwater-ridging mechanisms. This mechanism is still poorly understood despite the number of processes proposed and widespread acceptance (Cloke et al., 2006). Therefore, this case study can be considered the preliminary identification, recognition and quantification of the mechanisms at catchment scale.

\section{Conclusion}

According to the premises, the case study confirms the close link between geomorphometry and hydrology, since geomorphometry describes land surface quantitatively and land surface is the spatial expression of the geomorphic processes acting in time and resulting in landforms that are generated by hydrological mechanisms mainly in temperate and Mediterranean eco-regions. This demonstrates how geomorphometry can support hydrological analysis, by improving an interdisciplinary approach for future research developments in connecting hydrology and geomorphology in 
Table 4. Synoptic values of the $Q$-EC scenarios and contributing areas $(S)$ values for each hydro-geomorphotype. Legend: $q$ is the specific discharge calculated for the catchment area; A1 is the ratio between the contributing area and the hydro-geomorphotype; A2 is the ratio between the contributing area and the catchment area.

\begin{tabular}{|c|c|c|c|c|c|c|}
\hline $\begin{array}{l}\text { Hydro- } \\
\text { geomorphotype } \\
\text { (HGT) }\end{array}$ & Scenario & $\begin{array}{l}\text { Discharge } \\
Q\left(\mathrm{~L} \mathrm{~s}^{-1}\right)\end{array}$ & $\begin{array}{r}\text { Specific } \\
\text { discharge } \\
q\left(\mathrm{~L} \mathrm{~s}^{-1} \mathrm{~km}^{-2}\right)\end{array}$ & $\begin{array}{l}\text { Contributing } \\
S\left(\mathrm{~km}^{2}\right)\end{array}$ & A1 & A2 \\
\hline \multirow[t]{5}{*}{ Riparian corridor } & 1 & 50 & 16.47 & 0.057 & 0.143 & 0.018704 \\
\hline & 2 & 300 & 98.79 & 0.102 & 0.257 & 0.033638 \\
\hline & 3 & 600 & 197.58 & 0.157 & 0.396 & 0.051783 \\
\hline & 4 & 1000 & 329.30 & 0.227 & 0.570 & 0.074678 \\
\hline & 5 & 1900 & 625.68 & 0.576 & 1.448 & 0.189588 \\
\hline \multirow[t]{5}{*}{ Hillslope } & 1 & 50 & 16.47 & 0.001 & 0.00157 & 0.000486 \\
\hline & 2 & 300 & 98.79 & 0.003 & 0.00280 & 0.000864 \\
\hline & 3 & 600 & 197.58 & 0.015 & 0.0155 & 0.004783 \\
\hline & 4 & 1000 & 329.30 & 0.038 & 0.0400 & 0.012365 \\
\hline & 5 & 1900 & 625.68 & 0.420 & 0.447 & 0.138233 \\
\hline \multirow[t]{5}{*}{ Nose } & 1 & 50 & 16.47 & 0.00008 & 0.00012 & $2.47 \times 10^{-5}$ \\
\hline & 2 & 300 & 98.79 & 0.00020 & 0.00032 & $6.59 \times 10^{-5}$ \\
\hline & 3 & 600 & 197.58 & 0.001 & 0.00131 & 0.000272 \\
\hline & 4 & 1000 & 329.30 & 0.015 & 0.0241 & 0.005014 \\
\hline & 5 & 1900 & 625.68 & 0.119 & 0.188 & 0.039129 \\
\hline \multirow[t]{5}{*}{ Hollow } & 1 & 50 & 16.47 & 0.007 & 0.00994 & 0.002297 \\
\hline & 2 & 300 & 98.79 & 0.015 & 0.02151 & 0.004972 \\
\hline & 3 & 600 & 197.58 & 0.050 & 0.07109 & 0.016432 \\
\hline & 4 & 1000 & 329.30 & 0.093 & 0.13316 & 0.030782 \\
\hline & 5 & 1900 & 625.68 & 0.450 & 0.64116 & 0.148211 \\
\hline \multirow[t]{2}{*}{ Ridge } & 4 & 1000 & 329.30 & 0.00030 & 0.000814 & $9.88 \times 10^{-5}$ \\
\hline & 5 & 1900 & 625.68 & 0.005 & 0.0145 & 0.001762 \\
\hline
\end{tabular}

data acquisition, mapping, analysis, modeling and generalpurpose applications. This is the purpose of object-based hydro-geomorphology, based on the methods for recognizing and classifying distinctive hydro-objects within catchments, involving ontology and semantics of landforms and processes in significant catchment areas with distinctive hydrological behavior and response in order to allow for their objective description, holistic analysis and inter-catchment comparison.

From this perspective, firstly by means of a recursive training-target approach (Guida et al., 2015), good agreement was observed between expert-based geomorphological mapping and an object-based geomorphometric map.

Therefore, by combining hydro-chemical analysis and an object-based hydro-geomorphotype map, the variability of the contributing area during a significant storm event was spatially modeled using the log values of the flow accumulation. In spite of its simplicity, a good agreement was observed between the spatial distribution of these parameters with the observed contributing areas detected during the event by carrying out direct surveys and taking surface and groundwater discharge measurements. The runoff components were determined for the storm event under study and specific runoff discharge from each contributing hydro-geomorphotype was calculated for each time step on the hydro-chemograph.

This study is the experimental confirmation of the role and entity of pre-event water contributions to streamflow by the rapid mobilization of the capillary fringe inducing the groundwater-ridging mechanism in steep sloping terrains. This mechanism is still poorly understood despite the number of processes proposed and widespread acceptance (Cloke et al., 2006); therefore, this case study can be considered as being a preliminary identification, recognition and quantification of this particular mechanism at catchment scale. According to Marcus et al. (2004), this study emphasizes the fact that field-based process studies must "continue to form the underpinning of hydrologic application in GIS's" and "GIScience should not come at the expense of sacrificing field-based studies of hydrologic processes and responses".

This is an approach that can fill the gap between simple lumped hydrological models and sophisticated hydrological distributed models based on numerous quantitative parameters and expensive data collection. This kind of interdisciplinary and integrated approach can be applied to similar, rainfall-dominated, forested no-karst catchments in the Mediterranean eco-region by using an inexpensive, parsimo- 
nious and effective methodology for water resource assessment and management as suggested by the Biosphere 2 program. In fact, in UNESCO International Designation Areas (such as the Cilento Global Geopark), the Global Geopark Network mission must guarantee hydro-geodiversity in compliance with the regulations laid down by the World Heritage Cultural Landscape Management, and natural and managed ecosystems (A1) must be safeguarded as established by the MAN AND BIOSPHERE program.

From this perspective, geomorphometry plays a fundamental role in quantifying and objectively mapping hydrogeomorphological entities with hydrological relevance that require monitoring and modeling in production, transferring and routing the flows between the various units in the catchments, as the base knowledge of progressive ecological planning for the sustainable use of water resources and best practices in land use improvements.

\section{Data availability}

The underlying research data can be publicly accessed and are available from the Supplement.

\section{The Supplement related to this article is available online at doi:10.5194/hess-20-3493-2016-supplement.}

Competing interests. The authors declare that they have no conflict of interest.

Acknowledgements. The paper was financed with ORSA155417 University of Salerno research funds. The authors would like to thank Pasqualino Lovisi for taking field measurements, Giuseppe Benevento for his scientific support (CUGRI), Aniello Aloia and Angelo De Vita, Cilento Global Geopark manager and director, for their institutional support, and Mauro Biafore for the rainfall data obtained from the Campania region monitoring system.

Edited by: A. Guadagnini

Reviewed by: two anonymous referees

\section{References}

Ambroise, B.: Role hydrologique des surfaces saturées en eau dans le bassin du Ringelbach à Soultzeren (Hautes-Vosges), France, "Recherches sur l'Environnement dans la Région", Actes du 1er Colloque Scientifique des Universités du Rhin Supérieur, Université Louis Pasteur - Conseil de l'Europe, Strasbourg, France, 27-28 June 1986, 620-630, 1986.

Anders, N. S., Seijmonsbergen, A. C., and Bouten, W.: Segmentation optimization and stratified object-based analysis for semiautomated geomorphological mapping, Remote Sens. Environ., 115, 2976-2985, doi:10.1016/j.rse.2011.05.007, 2011.
Baatz, M. and Schäpe, A.: Multiresolution Segmentation: an optimization approach for high quality multi-scale image segmentation, in: Angewandte Geographische Informa tionsverarbeitung XII, edited by: Strobl, J., Blaschke, T., Griesebner, G., and Wichmann-Verlag, H., 12-23, 2000.

Babar, M.: Hydrogeomorphology, Foundamental applications and techniques, New India Publishing Agency, New Delhi, India, 2005.

Barling, R., Moore, I., and Grayson, R.: A Quasi-Dynamic Wetness Index for Characterizing the Spatial Distribution of Zones of Surface Saturation and Soil Water Content, Water Resour. Res., 30, 1029-1044, 1994.

Betson, R.: What is watershed runoff?, J. Geophys. Res., 69, 15411551, 1964.

Buchanan, B., Easton, Z., Schneider, R., and Walter, M.: Incorporating Variable Source Area Hydrology into a Spatially Distributed Direct Runoff Model, J. Am. Water. Resour. As., 48, 43-60, doi:10.1111/j.1752-1688.2011.00594.x, 2012.

Cascini, L., Cuomo, S., and Guida, D.: Typical source areas of May 1998 flow-like mass movements in the Campania region, Southern Italy, Eng. Geol., 96, 107-125, 2008.

Cloke, H., Anderson, M., McDonnell, J., and Renaud, J.-P.: Using numerical modelling to evaluate the capillary fringe groundwater ridging hypothesis of streamflow generation, J. Hydrol., 316, 141-162, 2006.

Conacher, A. J. and Dalrymple, J. B.: The nine unit landsurface model: An approach to pedogeomorphic research, Geoderma, 18, $1-154,1977$.

Cuomo, A.: The contribute of the Hydro-Geomorphology in the evaluation of the flood discharge in the Campania region, Phd thesis, University of Salerno, Fisciano, Italy, 2012.

Cuomo, A. and Guida, D.: Discharge-electrical conductivity relationship in the Ciciriello Torrent, a reference catchment of the Cilento, Vallo Diano and Alburni European Geopark (Southern Italy), Rendiconti on line Società Geologica Italiana, 28, 36-40, 2013.

Cuomo, A. and Guida, D.: Using hydro-chemograph analyses to reveal runoff generation processes in a mediterranean catchment, Hydrol. Process., doi:10.1002/hyp.10935, accepted, 2016.

Cuomo, A., Guida, D., Palmieri, V., and Rossi, R.: HydroGeomorphotype: A New Object-Based Unit in HydroGeomorphological Analysis and Modelling. IAG/AIG International Workshop on "Objective Geomorphological Representation Models: Breaking through a New Geomorphological Mapping Frontier", Abstract book, University of Salerno, 15-19 October 2012, 37-40, 2012.

Dragut, L. and Blaschke, T.: Automated classification of landform elements using object-based image analysis, Geomorphology, 81, 330-344, doi:10.1016/j.geomorph.2006.04.013, 2006.

Dragut, L., Minár, J., Csillik, O., and Evans, I. S.: Land-surface segmentation to delineate elementary forms from Digital elevation Models, Geomophometry, 1-5, 2013.

Dragut, L., Csillik, O., Eisank, C., and Tiede, D.: Automated parameterisation for multi-scale image segmentation on multiple layers, ISPRS J. Photogramm., 88, 119-127, doi:10.1016/j.isprsjprs.2013.11.018, 2014.

Dramis, F., Guida, D., and Cestari, A.: Nature and Aims of geomorphological mapping, in: Geomorphological mapping: Methods and applications, Developments in Earth Surface Processes, 
edited by: Smith, M., Paron, P., and Griffiths, J. S., Elsevier, Amsterdam, the Netherlands, 15, 39-73, 2011.

Dunne, T. and Black, R.: Partial Area Contributions to Storm Runoff in a Small New England Watershed, Water Resour. Res., 6, 1296-1311, 1970.

Dunne, T. and Leopold, L.: Water in Environmental Planning, W. H. Freeman and Co., New York, USA, 1978.

Dunne, T., Moore, T. R., and Taylor, C. H.: Recognition and prediction of runoff-producing zones in humid regions, Hydrological Sciences Bulletin, 20, 305-327, 1975.

Easton, Z., Fuka, D., Walter, M., Cowan, D., Schneiderman, E., and Steenhuis, T.: Re-Conceptualizing the Soil and Water Assessment Tool (SWAT) Model to Predict Runoff from Variable Source Areas, J. Hydrol, 348, 279-291,

Easton, Z., Gerard-Marchant, P., Walter, M., Petrovic, A., and Steenhuis, T.: Hydrologic Assessment of a Suburban Variable Source Watershed in the Northeast United States, Water Resour. Res., 43, W03413, doi:10.1029/2006WR005076, 2007. 2008.

Easton, Z. M., Fuka, D. R., White, E. D., Collick, A. S., Biruk Ashagre, B., McCartney, M., Awulachew, S. B., Ahmed, A. A., and Steenhuis, T. S.: A multi basin SWAT model analysis of runoff and sedimentation in the Blue Nile, Ethiopia, Hydrol. Earth Syst. Sci., 14, 1827-1841, doi:10.5194/hess-14-1827-2010, 2010.

Eisank, C., Smith, M., and Hillier, J.: Assessment of multiresolution segmentation for delimiting drumlins in digital elevation models, Geomorphology, 214, 452-464, doi:10.1016/j.geomorph.2014.02.028, 2014.

Goerl, R. F., Kobiyama, M., and dos Santos, I.: Hydrogeomorphology: principles, concepts, processes and applications, Revista Brasileira de Geomorfologia, 12, 103-111, 2012.

Guida, D. and Cuomo, A.: Using discharge-electrical conductivity relationship in a Mediterranean catchment: the T. Ciciriello in the Cilento, Vallo Diano and Alburni European Geopark (Southern Italy), Eng. Geol. for Society and Territory, Torino, Springer International Publishing, Switzerland, 3, 201-205, 2014.

Guida, D., Cestari, A., Cuomo, A., Dramis, F., Palmieri, V., Paron, P., and Siervo, V.: The geomorphological informative mapping system of Salerno University: an overview, Proceedings of the IAG/AIG International Workshop on "Objective Geomorphological Representation Models: Breaking through a New Geomorphological Mapping Frontier", University of Salerno, Fisciano, Italy, 71-72, 2012.

Guida, D., Cuomo, A., Cestari, A., Dramis, F., Palmieri, V., and Siervo, V.: The Salerno University Geomorphological Informative Mapping System: the Licosa polygentic case study (Cilento European Geopark, southern Italy), in: Geomorphometry for Geosciences, Adam Mickiewicz University in Poznan, Institute of Geoecology and Geoinformation, International Society for Geomorphometry, edited by: Jasiewicz, J., Zwolinski, Z., Mitasova, H., and Hengl, T., 53-56, 2015.

Hengl, T.: Finding the right pixel size, Computers \& Geosciences, 32, 1283-1298, doi:10.1016/j.cageo.2005.11.008, 2006.

Hennrich, K., Schmidt, J., and Dikau, R.: Regionalization of geomorphometric parameters in hydrologic modelling using GIS, Regionalization in Hydrology, edited by: Diekkruger, B., Kirkby, M., and Schroder, U., IAHS Publication 254, Proceedings of the Conference on Regionalization in Hydrology at Braunschweig, March 1997, International Association of Hydrological Sciences, Wallingford, UK, 181-191, 1999.
Hewlett, J. D.: Soil moisture as a source of base flow from steep mountain watersheds, US Forest Scrv. Southeast, Forest Expt. Sta. Paper, 192, 1-11, 1961.

Huang, C. and Laflen, J.: Seepage and Soil Erosion for a Clay Loam Soil, Soil Sci. Soc. Am. J., 60, 408-416, 1996.

Klaus, J. and McDonnell, J. J.: Review paper: Hydrograph separation using stable isotopes: Review and evaluation, J. Hydrol., 505, 47-64, 2013.

Kwaad, F.: Summer and Winter Regimes of Runoff Generation and Soil Erosion on Cultivated Loess Soils (The Netherlands), Earth Surf. Processes, 16, 653-662, 1991.

Ladouche, B., Probst, A., Viville, D., Idir, S., Baqué, D., Loubet, M., and Bariac, T.: Hydrograph separation using isotopic, chemical and hydrological approaches (strengbach catchment, France), J. Hydrol., 242, 255-274, 2001.

Latron, J.: Caractérisation géomorphologique et hydrologique du bassin versant versant du Strengbach (Aubure), Memoire de Maitrise, UFR de Géographie, CEREG, Université Louis Pasteur, Strasbourg, France, 1990.

Latron, J. and Gallart, F.: Seasonal dynamics of runoff-contributing areas in a small mediterranean research catchment (Vallcebre, Eastern Pyrenees), J. Hydrol., 335, 194-206, 2007.

Longobardi, A., Guida, D., Cuomo, A., and Villani, P.: Chemical streamflow analysis as a support for hydrograph filtering in small size watersheds: the Ciciriello experimental catchment (Cilento, Vallo di Diano and Alburni European and Global Geopark), in: WSEAS, edited by: Ceron Breton, J. G., Quartieri, J., Guida, M., Guida, B., and Guarnaccvia, C., Vietri (SA), Italy, 96-102, 2014.

Longobardi, A., Villani, P., Guida, D., and Cuomo, A.: Hydro-geochemical streamflow analysis as a support for digital hydrograph filtering in a small, rainfall dominated, sandstone watershed, J. Hydrol., 539, 177-187, 2016.

Lyon, S., Walter, M. T., Gerard-Marchant, V., and Steenhuis, T.: Using a Topographic Index to Distribute Variable Source Area Runoff Predicted with the SCS Curve-Number Equation, Hydrol. Process., 18, 2757-2771, 2004.

Marcus, A. W., Aspinall, R. J., and Marston, R. A.: Geographic information systems and surface hydrology in mountains, In M. P. Bishop and J. F. Shroder Jr, Geographic information science and mountain geomorphology, Chilchester, UK, Springer-Praxis, 344-370, 2004.

Martinez Fernandez, J., Ceballos Barbancho, A., Hernández Santana, V., Casado Ledesma, S., and Morán Tejeda, C.: Procesos hidrológicos en una cuenca forestada del Sistema Central: Cuenca experimental de Rinconada, Cuadernos de Investigacion Geografica 31, 7-25, 2005.

Moore, I., Burch, G., and Mackenzie, D.: Topographic Effects on the Distribution of Surface Soil Water and the Location of Ephemeral Gullies, Transaction ASAE, 31, 1098-1107, 1988.

Myrabo, S.: Runoff studies in a small catchment, Nord. Hydrol., 17, 335-346, 1986.

National Research Council: New strategies for America's watrshed. Wasshinghton, D.C., National Academy Press, New York, USA, 1999.

Okunishi, K.: Hydrogeomorphological interactions: A review of approach and strategy, Trans. Jpn. Geomorph. Union, 12, 99-16, 1991.

Okunishi, K.: Concept and methodology of hydrogeomorphology, Trans. Jpn. Geomorph. Union, 15, 5-18, 1994. 
Peckham, S. D.: Geomorphometry and spatial hydrologic modelling, in: Geomorphometry: concets, software, applications, edited by: Hengl, T. and Reuter, H. J., Elsevier, Amsterdam, the Netherlands, 579-602, 2009.

Pionke, H., Gburek, W., Sharpley, A., and Schnabel, R.: Flow and Nutrient Export Patterns for an Agricultural Hill Land Watershed, Water Resour. Res., 32, 1795-1804, 1996.

Sidle, R. C. and Onda, Y.: Hydrogeomorphology: overview of an emerging science, Hydrol. Process., 18, 597-602, 2004.

Sidle, R. C., Tsuboyama, Y., Noguchi, S., Hosoda, I., Fujieda, M., and Shimizu, T.: Stormflow generation in steep forested headwaters: a linked hydrogeomorphic paradigm, Hydrol. Process., 14, 369-385, 2000.

van Asselen, S. and Seijmonsbergen, A. C.: Expert-driven semi-automated geomorphological mapping for a mountainous area using a laser DTM, Geomorphology, 78, 309-320, doi:10.1016/j.geomorph.2006.01.037, 2006.
Vander Kwaak, J. and Loague, K.: Hydrologic-Response Simulations for the R-5 Catchment with a Comprehensive PhysicsBased Model, Water Resourc. Res., 37, 999-1013, 2001.

White, E., Easton, Z., Fuka, D., Collick, A., Adgo, E., Mc-Cartney, M., Awulachew, S. B., Selassie, Y. G., and Steenhuis, T. S.: Development and Application of a Physically Based Landscape Water Balance in the SWAT Model, Hydrol. Process., 25, 915-925. doi:10.1002/hyp.7876, 2011.

Zollweg, J., Gburek, W., Pionke, and Sharpley, A.: GIS-Based Delineation of Source Areas of Phosphorus Within Agricultural Watersheds of the Northeastern USA. Proceedings of the IAHS Symposium on Modeling and Management of Sustainable BasinScale, Colorado, 10-14 July 1995, Boulder, CO, USA, 31-39, 1995. 